\title{
PENGARUH PENGEMBANGAN KARIR TERHADAP MOTIVASI KERJA KARYAWAN PT. BANK BUKOPIN, TBK CABANG PALEMBANG
}

\author{
Haikal, S.E. M.Si \\ Dosen PNSD Pada Fakultas Ekonomi \\ Universitas Palembang
}

\begin{abstract}
ABSTRAK
Tujuan penelitian ini adalah untuk mengetahui Pengaruh Pengembangan Karir terhadap Motivasi Kerja Karyawan PT. Bank Bukopin Tbk. Dalam penelitian ini yang dimaksud adalah semua karyawan yang ada di PT. Bank Bukopin Tbk. Cabang Palembang berjumlah 115 orang, namun yang diambil sebagian sampel hanya 53 orang dengan metode simple random sampling.

Dari hasil pengolahan data diperoleh persamaan regresi linear sederhana $y=0,664+$ 0,804 X dengan nilai koefisien determinasi sebesar 0,341, ini menunjukkan bahwa besarnya pengaruh pengembangan karir terhadap motivasi kerja karyawan PT. Bank Bukopin Tbk. Cabang Palembang adalah sebesar 34,1\%, sedangkan dari hasil perhitungan nilai koefisien korelasi diperoleh sebesar 0,561. Ini berarti mempunyai hubungan yang sangat kuat antara pengembangan karir dan motivasi kerja karyawan PT. Bank Bukopin Tbk. Cabang Palembang. Juga didapat nilai $t_{\text {hitung }}$ sebesar 4,83 dan $t_{\text {tabel }}$ sebesar 2,01 yang hasilnya nilai $t_{\text {hitung }}>t_{\text {tabel }}$. Hal ini berarti $H_{0}$ ditolak sehingga dapat disimpulkan bahwa pengembangan karir memiliki pengaruh signifikan terhadap motivasi kerja karyawan PT. Bank Bukopin Tbk. Cabang Palembang.
\end{abstract}

\section{Kata Kunci : Pengembangan Karir, Motivasi.}

\section{PENDAHULUAN}

\subsection{Latar Belakang}

Bank Bukopin yang sejak berdirinya tanggal 10 Juli 1970 menfokuskan diri pada segmen UMKMK, saat ini telah tumbuh dan berkembang menjadi bank yang masuk ke kelompok bank menengah di Indonesia dari sisi aset. Seiring dengan terbukanya kesempatan dan peningkatan kemampuan melayani kebutuhan masyarakat yang lebih luas, Bank Bukopin telah mengembangkan usahanya ke segmen komersial dan konsumer. Kedua segmen ini merupakan pilar bisnis Bank Bukopin, dengan pelayanan secara konvensional maupun syariah, yang didukung oleh sistem pengelolaan dana yang optimal, kehandalan teknologi informasi, kompetensi sumber daya manusia dan praktek tata kelola perusahaan yang baik. Landasan ini memungkinkan Bank Bukopin melangkah maju dan menempatkannya sebagai suatu bank yang kredibel. Operasional Bank Bukopin kini didukung oleh lebih dari 280 kantor yang tersebar di 22 provinsi di seluruh Indonesia yang terhubung secara real time on-line. Bank Bukopin juga telah membangun jaringan micro-banking yang diberi nama "Swamitra", yang kini berjumlah 543 outlet, sebagai wujud program kemitraan dengan koperasi dan lembaga keuangan mikro.

Pengaruh perkembangan karir suatu hal yang menjadi titik fokus utama seorang karyawan di suatu perusahaan. Motivasi dalam suatu pekerjaan dinilai sangat berpengaruh terhadap kinerja seorang karyawan di suatu perusahaan. Untuk mencapai suatu karir yang berkembang dalam suatu perusahaan tentunya diperlukan upaya yang besar dan juga beberapa tahapan yang harus dilalui seorang karyawan guna menggapai karir yang lebih tinggi. Proses pengembangan sumber daya manusia 
khususnya pengembangan karir pada PT. Bank Bukopin selain untuk mengetahui tujuan karir juga untuk mengetahui jenjang yang mengarah pada tujuan tersebut. Adanya masalah yang terdapat dalam objek penelitian ini yaitu pada Bank Bukopin pengembangan karir yang bisa didapatkan dalam perusahaan ini dinilai sangatlah kurang dikarenakan terdapat beberapa karyawan yang karirnya tidak berjalan dengan baik. Berdasarkan pengamat peneliti terhadap objek penelitian didapatkan informasi bahwa terdapat ada beberapa karyawan yang sudah lebih dari 5 tahun masih tetap berada diposisi yang sama dan karir yang sama. Hal ini disebabkan kurangnya kesempatan yang diberikan oleh perusahaan dan kesempatan pengembangan karir karyawan tersebut. Dikarenakan banyaknya karyawan yang sudah berdedikasi selama bertahun-tahun tetapi belum mendapatkan karir yang layak dan belum bisa mendapatkan kesempatan berkembang di Bank Bukopin, maka penulis ingin mencari tahu adakah pengaruh pengembangan karir tersebut terhadap motivasi kerja karyawan di Bank Bukopin, karena jika pengembangan karir mempunyai pengaruh yang signifikan terhadap motivasi kerja karyawan di Bank Bukopin maka seharusnya perusahaan tersebut memberikan kesempatan berkembang yang lebih banyak lagi agar karyawan bisa lebih termotivasi dan bisa menghasilkan kinerja yang lebih baik guna memberikan keuntungan yang besar terhadap perusahaan tersebut.

Dari uraian di atas, maka penulis tertarik untuk melakukan penelitian dengan judul "Pengaruh Pengembangan Karir Terhadap Motivasi Kerja Karyawan PT. Bank Bukopin Tbk Cabang Palembang”.

\subsection{Rumusan Masalah}

Berdasarkan latar belakang yang telah diuraikan di atas maka perumusan masalahnya adalah "Adakah pengaruh pengembangan karir terhadap motivasi kerja karyawan PT. Bank Bukopin Tbk Cabang Palembang".

\subsection{Tujuan Penelitian}

Tujuan dari penelitian ini adalah untuk mengetahui pengaruh pengembangan karir terhadap motivasi kerja karyawan PT. Bank Bukopin Tbk. Cabang Palembang.

\subsection{Manfaat Penelitian}

Adapun manfaat yang diharapkan dari penelitian ini agar dapat memberikan masukan dalam pelaksanaan sistem pengembangan karir yang lebih baik bagi PT. Bank Bukopin Tbk. Cabang Palembang.

\section{TINJAUAN PUSTAKA}

\subsection{Landasan Teori}

\subsubsection{Pengertian Pengembangan Karir}

Menurut Veithzal Rivai \& Sagala J (2010:274) pengembangan karir adalah proses peningkatan kemampuan kerja individu yang dicapai dalam rangka mencapai karir yang diinginkan.

Menurut Notoatmodjo (2009: 169), ada beberapa variabel atau indikatorindikator yang perlu diperhatikan dalam pengembangan karir, antara lain sebagai berikut :

\section{Kinerja}

Pengembangan karir yang selalu dikaitkan dengan kinerja seorang pegawai dalam organisasi. Apabila pegawai mempunyai kinerja baik, maka ia mempunyai kesempatan untuk mengembangkan karirnya.

\section{Loyalitas}

Loyalitas atau integritas yang tinggi seseorang pegawai akan menjadi acuan pimpinan dalam pengembangan karirnya. Apabila loyalitas pegawainya rendah/tidak mempunyai integritas, maka karirnya pasti akan terhambat.

3. Dikenal

Pegawai yang kinerjanya baik, loyalitasnya tinggi, sudah barang tentu akan lebih dikenal oleh atasan, sehingga faktor ini akan mempengaruhi pengembangan karirnya.

\section{Bawahan}

Peran bawahan juga ikut menentukan dalam pengembangan karir. Oleh sebab itu pimpinan harus pandai dalam memanfaatkan 
bawahannya, terutama bawahan yang mempunyai keterampilan tertentu.

5. Kesempatan pengembangan

Selain hal-hal tersebut, pegawai juga harus pandai memanfaatkan waktu, keterampilan, mengikuti seminar yang terkait dengan pekerjaan atau tugas yang diembannya.

\subsubsection{Tujuan Pengembangan Karir}

Menurut Veithzal Rivai \& Sagala J (2010:291) bahwa pengembangan karir yang dirancang secara baik akan membantu dalam menentukan kebutuhan karir mereka sendiri dan menyesuaikan antara kebutuhan karyawan dengan tujuan perusahaan.

Adapun tujuan pengembangan karir yang dikemukakan oleh Andrew J. Dubrin (1982:198) yang dikutip oleh Anwar Prabu Mangkunegara (2017:77) adalah sebagai berikut:

1. Membantu tercapainya tujuan perusahaan dan tujuan pribadi.

2. Meningkatkan kesejahteraan dan loyalitas.

3. Menyadarkan karyawan akan kemampuannya untuk menduduki suatu jabatan tertentu.

4. Memperkuat hubungan antara karyawan dan perusahaan.

5. Meenciptakan suasana kerja yang sehat atau positif.

6. Membantu terlaksananya program lain yang diingikan perusahaan tercapai.

7. Turnover dan biaya kepegawaian lebih efektif.

8. Menghidari kebosanan profesi dan manajerial.

9. Meningkatkan pengintegrasian dalam perencanaan pegawai.

\subsubsection{Faktor-Faktor yang Mempengaruhi Pengembangan Karir}

Menurut Veithzal Rivai \& Sagala J

(2010:278) faktor- faktor yang mempengaruhi pengembangan karier adalah sebagai berikut :

1. Prestasi kerja (Job Performance)

2. Jaringan kerja

3. Pembimbing dan sponsor
4. Peluang untuk tumbuh

\subsubsection{Pengertian Motivasi Kerja}

Menurut Robbins (2014:213) motivasi adalah proses yang ikut menentukan intensitas, arah, dan ketekunan individu dalam usaha mencapai sasaran.

Motivasi menurut A. Sunyoto Munandar (2006:136) adalah suatu proses dimana kebutuhan-kebutuhan mendorong seseorang untuk melakukan serangkaian kegiatan yang mengarah ke tercapainya tujuan tertentu. Bila kebutuhan telah terpenuhi maka akan dicapai suatu kepuasan. Sekelompok kebutuhan yang belum terpuaskan akan menimbulkan ketegangan, sehingga perlu dilakukan serangkaian kegiatan untuk mencari pencapaian tujuan khusus yang dapat memuaskan kelompok kebutuhan tadi, agar ketegangan menjadi berkurang. Motivasi adalah serangkaian sikap dan nilai-nilai yang mempengaruhi individu untuk mencapai hal yang spesifik sesuai dengan tujuan individu. Veithzal Rivai \& Sagala J (2010: 837)

Menurut para ahli dikembangkan dalam buku Sedarmayanti (2011:233) motivasi adalah :

1. Keinginan yang terdapat pada seorang individu yang merangsangnya melakukan tindakan (George R Terry)

2. Proses dengan mana prilaku dibangkitkan, diarahkan dan dipertahankan selama berjalannya waktu (Porter \& Lawler)

3. Kekuatan kecenderungan seseorang individu melibatkan diri dalam kegiatan yang berarahkan sasaran dalam pekerjaan. (Richard M. Steers)

\subsubsection{Teori Motivasi Kerja}

\section{A. Teori Motivasi Maslow}

Menurut Abraham Maslow yang dikutip oleh Sedarmayanti (2011:234), manusia itu mempunyai lima tingkat kebutuhan:

1. Kebutuhan Fisiologis, yaitu kebutuhan tingkat dasar (makan, minum, pakaian, dan perumahan). 
2. Kebutuhan keamanan, yaitu kebutuhan keselamatan dan perlindungan terhadap kerugian fisik dan emosional.

3. Kebutuhan Sosial, yaitu kebutuhan kasih sayang, dimiliki, diterima baik dan persahabatan.

4. Kebutuhan Penghargaan, yaitu kebutuhan rasa hormat, harga diri, otonomi, prestasi, pengakuan dan perhatian.

5. Kebutuhan Aktualisasi diri, yaitu dorongan untuk menjadi apa yang ia mampu, mencakup pertumbuhan, mencapai potensialnya, dan pemenuhan diri.

\section{B. Teori Motivasi Frederick Herzberg}

Menurut Herzberg, motivasi kerja karywan dapat dibedakan menjadi dua, yang dikenal dengan:

\section{Teori X}

Pengandaian bahwa karyawan itu negatif, tidak menyukai kerja, malas, menghindari tanggung jawab, harus dipaksa, diawasi dan diancam dengan hukuman.

\section{Teori Y}

Pengandaian bahwa karyawan itu positif, menyukai kerja, kreatif, berusaha bertanggung jawab.

\subsubsection{Faktor-Faktor yang Mempengaruhi Motivasi Kerja}

Seorang karyawan dalam suatu perusahaan harus mempunyai motivasi dalam bekerja agar bisa mencapai efektivitas kinerja yang maksimal. Motivasi kerja merupakan suatu faktor pendorong bagi karyawan untuk bekerja lebih baik dan ia dipengaruhi oleh beberapa faktor, antara lain seperti yang dikemukakan oleh Wahdjosumidjo (1993:92) faktor-faktor yang mempengaruhi motivasi kerja adalah faktor ekstern dan intern. Faktor ekstern antara lain adalah kebijakan yang telah ditetapkan, tersedianya sarana dan prasarana yang mendukung pelaksanaan pekerjaan. Sedangkan faktor intern adalah kemampuan bekerja, tanggung jawab, serta produktivitas kerja.

\subsection{Penelitian Terdahulu}

Tabel 2.1 Penelitian Terdahulu

\begin{tabular}{|c|c|c|}
\hline No & Judul Skripsi & Hasil Penelitian \\
\hline 1 & $\begin{array}{l}\text { Pengaruh } \text { Pengembangan Karir } \\
\text { Terhadap Motivasi Kerja Karyawan } \\
\text { Pada Pada PT. Excel Utama Indonesia } \\
\text { Karawang. } \\
\text { Sumber : Jurnal oleh Puji Sungkono } \\
\text { Volume } 10 \text { No2 Januari } 2013 . \\
\text { Fakultas Ekonomi dan Bisnis } \\
\text { Universitas Singaperbangsa Karawang }\end{array}$ & $\begin{array}{l}\text { Hasil Uji t tabel }=1,667 \text { dengan } \mathrm{t} \text { hitung }=8,068 \text {. Hasil } \\
\text { perhitungannilai thitung yang lebih besar dari } \mathrm{t} \text { tabel dan } \\
\text { ini menyatakan bahwa ada pengaruh yang signifikan } \\
\text { antara pengembangan karir terhadap motivasi kerja } \\
\text { karywan pada PT. Excel Utama Indonesia Karawang. }\end{array}$ \\
\hline 2 & $\begin{array}{l}\text { Pengaruh Pengembangan Karir } \\
\text { Terhadap Motivasi Kerja Karyawan } \\
\text { PT. Jasa Raharja (Persero) Cabang } \\
\text { Sumatera Selatan. } \\
\text { Sumber : Skripsi oleh Marlina Zulpa } \\
\text { Resa, Fakultas Ekonomi Jurusan } \\
\text { Ekonomi Manajemen Universitas } \\
\text { PGRI Palembang }\end{array}$ & $\begin{array}{l}\text { Hasil penelitian menunjukan hubungan antara } \\
\text { pengembangan karir terhadap motivasi kerja karyawan } \\
\text { PT Jasa Raharja (Persero) Cabang Sumatera } \\
\text { Selatanadalah rendah dengan koefisien korelasi0,397\%, } \\
\text { kontribusi pengembangan karir terhadap motivasi kerja } \\
\text { karyawan sebesar } 15,76 \% \text { dan sisanya dipengaruhi oleh } \\
\text { variabel lain yang tidak diteliti dalam penelitian ini. } \\
\text { Persamaan regresi linier sederhana adalah Y }=18,783+ \\
0,457 \text { X serta kesimpulan hipotesis bahwa ada pengaruh } \\
\text { Pengembangan karir terhadap Motivasi Kerja Karyawan } \\
\text { pada PT Jasa Raharja (Persero) Cabang Sumatera } \\
\text { Selatan. }\end{array}$ \\
\hline
\end{tabular}




\subsection{Kerangka Fikir}

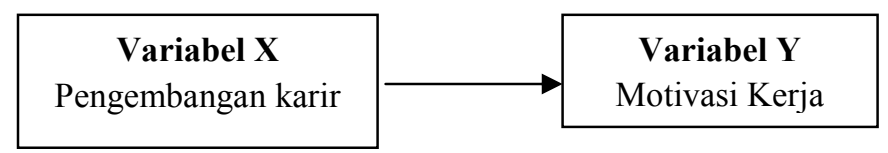

\subsection{Hipotesis}

Menurut Husein Umar (2016:104), Hipotesis merupakan suatu perumusan sementara mengenai suatu hal yang dibuat untuk menjelaskan hal itu dan juga dapat menuntun/mengarahkan penelitian selanjutnya.

Ho : Tidak ada pengaruh antara pengembangan karir terhadap motivasi kerja karyawan pada PT. Bank Bukopin Tbk Cabang Palembang

Ha : Ada pengaruh antara pengembangan karir terhadap motivasi kerja karyawan pada PT. Bank Bukopin Tbk Cabang Palembang

\section{METODOLOGI PENELITIAN}

\subsection{Objek Penelitian}

Dalam penulisan ini yang menjadi objek penelitian adalah PT. Bank Bukopin Tbk. Cabang Palembang.

\subsection{Ruang Lingkup Penelitian}

Mengingat terlalu luasnya faktorfaktor yang mempengaruhi motivasi kerja karyawan, maka penulis hanya membatasi masalah pada pengaruh pengembangan karir terhadap motivasi kerja karyawan PT. Bank Bukopin Cabang Palembang.

\subsection{Desain Penelitian}

Desain penelitian ini adalah penelitian asosiatif kausal dengan menggunakan pendekatan kuantitatif. Penelitian asosiatif klausal adalah penelitian yang bertujuan untuk mengetahui pengaruh antara dua variabel atau lebih Umi Narimawati (2012:34). Adapun pendekatan yang digunakan pada penelitian ini adalah pendekatan kuantitatif, karena data yang digunakan untuk menganalisis hubungan antara variabel dinyatakan dengan angka atau skala numerik.

\subsection{Jenis dan Sumber Data} ini adalah :

Data yang digunakan dalam penelitian

A. Data Primer

Data Primer merupakan data yang diperoleh dengan survei lapangan yang menggunakan semua metode pengumpulan data original Mudrajad Kuncoro (2014:127). Adapun data primer dalam penelitian ini berasal dari jawaban seluruh karyawan PT. Bank Bukopin Tbk. Cabang Palembang terhadap daftar pertanyaan yang disebarkan berdasarkan indikator-indikator dalam penelitian ini.

B. Data Sekunder

Data Sekunder merupakan data yang biasanya diperoleh dari lembaga pengumpul data dan dipublikasikan yang ada hubungan dengan penulisan penelitian ini.

\subsection{Populasi dan Sampel}

Populasi dalam penelitian ini adalah semua karyawan PT. Bank Bukopin Tbk. Cabang Palembang yang berjumlah 115 orang. Adapun metode pengambilan sampel yang dilakukan adalah dengan menggunakan rumus Slovin (Sugiono, 2011:87).

$$
n=\frac{N}{1+N(e)^{2}}
$$

Keterangan :

$\mathrm{N}=$ Ukuran sampel/jumlah responden

$\mathrm{N}=$ Ukuran Populasi

$\mathrm{E}=$ Persentase kelonggaran ketelitian kesalahan pengambilan sampel yang masih

bisa ditolerir, $\mathrm{e}=0,1$.

$$
\begin{aligned}
& n=\frac{115}{1+115(0,1)^{2}} \\
& n=\frac{115}{1+1,15}
\end{aligned}
$$




$$
\begin{aligned}
& n=\frac{115}{2,15} \\
& n=53,48
\end{aligned}
$$

Jadi jumlah sampel dalam penelitian pada PT. Bank Bukopin Tbk. Cabang Palembang ini adalah sebanyak 53 reponden.

\subsection{Definisi Operasional dan Pengukuran Variabel}

\begin{tabular}{|c|c|c|c|}
\hline Variabel & $\begin{array}{c}\text { Definisi Operasional } \\
\text { Variabel }\end{array}$ & Dimensi Penelitian & $\begin{array}{l}\text { Instrumen } \\
\text { Penelitian }\end{array}$ \\
\hline $\begin{array}{l}\text { Pengembangan } \\
\text { Karir (X) }\end{array}$ & $\begin{array}{l}\text { Pengembangan karir } \\
\text { adalah aktivitas } \\
\text { kepegawaian yang } \\
\text { membantu pegawai- } \\
\text { pegawai merencanakan } \\
\text { karir masa depan mereka } \\
\text { di perusahaan agar } \\
\text { perusahaan dan pegawai } \\
\text { yang bersangkutan dapat } \\
\text { mengembangkan diri } \\
\text { secara maksimum. }\end{array}$ & $\begin{array}{l}\text { 1. Prestasi Kerja } \\
\text { 2. Jaringan Kerja } \\
\text { 3. Pembimbing dan } \\
\text { sponsor } \\
\text { 4. Peluang untuk tumbuh }\end{array}$ & $\begin{array}{c}1-2 \\
3 \\
4-5 \\
6-9\end{array}$ \\
\hline $\begin{array}{l}\text { Motivasi Kerja } \\
\text { (Y) }\end{array}$ & $\begin{array}{l}\text { Suatu proses dimana } \\
\text { kebutuhan-kebutuhan } \\
\text { mendorong seseorang } \\
\text { untuk melakukan } \\
\text { serangkaian kegiatan } \\
\text { yang mengarah ke } \\
\text { tercapainya tujuan } \\
\text { tertentu. }\end{array}$ & $\begin{array}{l}\text { 1. Kebijakan yang telah } \\
\text { ditetapkan } \\
\text { 2. Tersedianya sarana } \\
\text { dan prasarana }\end{array}$ & $\begin{array}{l}10-11 \\
11-14\end{array}$ \\
\hline
\end{tabular}

Tabel 3.1 Definisi Operasional Variabel

\subsection{Teknik Analisis}

\subsubsection{Uji Validitas dan Reliabilitas}

\section{Uji Validitas}

Menurut Sugiyono (2011:121) Uji Validitas adalah ketepatan antara data yang terkumpul dengan data yang sesungguhnya terjadi pada obyek yang diteliti. Teknik uji yang digunakan adalah teknik korelasi melalui koefisien korelasi product moment. Skor ordinal keseluruhan item, jika koefisien korelasi tersebut positif, maka item tersebut valid, sedangkan jika negatif maka item tersebut tidak valid dan akan dikeluarkan dari kuesioner atau digantikan dengan pernyataan perbaikan. Rumus Korelasi Product Moment menurut Sugiyono (2011:183) :

Keterangan :

$$
\boldsymbol{r}_{x y}=\frac{n\left(\sum X Y\right)-\left(\sum X\right),\left(\sum Y\right)}{\sqrt{\left\{n \cdot \sum X^{2}-\left(\sum X\right)^{2} \cdot\left(n \cdot \sum Y^{2}-\left(\sum Y\right)^{2}\right\}\right.}}
$$

$\mathrm{r}_{\mathrm{xy}}$ : Menunjukkan indeks korelasi antara dua variabel yang dikorelasikan

$\mathrm{R}$ : Koefisien validitas item yang dicari dua variabel yang dikorelasikan

$\mathrm{X}$ : Skor untuk pernyataan yang dipilih

Y : Skor total yang diperoleh dari seluruh item 
$\sum \mathrm{X}$ : Jumlah skor dalam distribusi $\mathrm{X}$

$\sum \mathrm{Y}:$ Jumlah skor dalam distribusi $\mathrm{Y}$

$\sum \mathrm{X}^{2}$ : Jumlah kuadrat dalam skor distribusi $\mathrm{X}$

$\sum \mathrm{Y}^{2}$ : Jumlah kuadrat dalam skor distribusi $\mathrm{Y}$

$\mathrm{N}$ : Banyaknya responden

2. Uji Reliabilitas

Hasil penelitian yang reliabel, bila terdapat kesamaan data dalam waktu yang berbeda Sugiyono (2011:121). Uji reliabilitas instrumen dengan skor antara 1-5 menggunakan rumus Cronbach's Alpha, menurut Arikunto. S (2010:239) dengan rumus sebagai berikut :

$$
r_{11}=\left[\frac{k}{(k-1)}\right]\left[1-\frac{\sum \sigma_{b}^{2}}{\sigma_{t}^{2}}\right]
$$

Keterangan :

$\mathrm{r}_{11} \quad$ : Koefisien realiabilitas alpha

$\mathrm{k} \quad$ : Jumlah item pernyataan

$\sum \sigma^{2} \mathrm{~b}:$ Jumlah varian butir

$\sigma^{2} \mathrm{t} \quad$ : Varians total

Setelah diperoleh harga $\mathrm{r}_{\text {hitung, }}$, selanjutnya untuk dapat dipastikan instrumen reliabel atau tidak, harga tersebut dikonsultasikan dengan harga $r_{\text {tabel }}$ untuk taraf kesalahan 5\% maupun 1\% maka dapat disimpulkan instrumen tersebut reliabel dan dapat dipergunakan untuk penelitian.

\subsubsection{Analisis Regresi Linear Sederhana}

Untuk menganalisis data yang digunakan dalam penelitian ini, maka penulis menggunakan metode statistik untuk mengetahui pengaruh pengembangan karir $(X)$ terhadap motivasi kerja $(Y)$. Persamaan regresi linear sederhana adalah rumus menggunakan menurut Riduwan dan Akdon (2013:133).

$$
\hat{Y}=a+b X
$$

\section{Dimana :}

$\hat{Y}=$ Subjek dalam variabel dependen yang dapat diproyeksikan.

$\mathrm{X}=$ Subjek pada Variabel bebas yang mempunyai nilai tertentu.

$\mathrm{a}=$ Nilai konstanta harga $\mathrm{Y}$ jika $\mathrm{X}=0$

$\mathrm{b}=$ Angka arah atau koefisen, yang menunjukan angka peningkatan ataupun penurunan variabel

Nilai a dan $b$ dapat dihitung dengan persamaan:

$$
a=\frac{(\Sigma y)\left(\Sigma x^{2}\right)-(\Sigma x)(\Sigma x y)}{n \sum x^{2}-(\Sigma x)^{2}}
$$

$$
\mathbf{b}=\frac{\mathbf{n} \sum \mathbf{x y}-\left(\sum \mathbf{x}\right)(\Sigma \mathbf{y})}{\mathbf{n} \sum \mathbf{x}^{2}-\left(\sum \mathbf{x}\right)^{2}}
$$




\section{Keterangan :}

$$
\begin{aligned}
& \Sigma \mathrm{X}=\text { Jumlah Skor Item } \\
& \Sigma \mathrm{Y}=\text { Jumlah Skor Total } \\
& \mathrm{n} \quad=\text { Responden } \\
& \mathrm{a}=\text { Harga } \mathrm{Y} \text { ketika } \mathrm{X}=0 \text { (harga } \\
& \text { konstanta) } \\
& \mathrm{b}=\text { Angka arah koefisien }
\end{aligned}
$$

\subsubsection{Koefisien Determinasi dan Koefisien Korelasi}

Analisa Koefisien Determinasi (R2) dimaksudkan untuk mengetahui tingkat ketepatan yang paling baik dalam analisa regresi, hal ini ditunjukkan oleh besarnya koefisien determintasi (R2) antara 0 (nol) sampai dengan 1 (satu). Jika koefisien determinasi nol berarti variabel independen sama sekali tidak berepengaruh terhadap variabel dependen. Apabila koefisien determinasi semakin mendekati satu, maka dapat dikatakan bahwa variabel independen berpengaru terhadap variabel dependen. Ghozali (2018:87). Dengan dilakukan perhitungan statistik dengan menggunakan rumus koefisien determinan menurut Nana Sudjana (2017:370).

$$
r^{2}=\frac{b\left(n\left(\sum X Y\right)-\left(\sum X\right) \cdot\left(\sum Y\right)\right)}{\sqrt{n \sum Y^{2}-(Y)^{2}}}
$$

Analisa Korelasi ini digunakan untuk mencari hubungan dan membuktikan hipotesis hubungan dua variabel. Rumus yang digunakan menurut Nana Sudjana (2017:371) adalah :

$$
r=\sqrt{r^{2}}
$$

Korelasi dilambangkan (r) dengan ketentuan nilai $r$ tidak lebih dari $(-1 \leq \mathrm{r} \geq+$ 1). Apabila nilai $r=-1$ artinya korelasinya negatif sempurna ; $\mathrm{r}=0$ artinya tidak ada korelasi ; dan $\mathrm{r}=1$ berarti korelasinya sangat kuat. Sedangkan arti harga $r$ akan dikonsultasikan dengan Tabel interprestasi Nilai r sebagai berikut :
TABEL 3.2 Pedoman untuk memberikan Interprestasi terhadap Koefisien Korelasi

\begin{tabular}{|c|c|}
\hline Interval & Tingkat Hubungan \\
\hline $0,80-1,000$ & Sangat Kuat \\
$0,60-0,799$ & Kuat \\
$0,40-0,599$ & Cukup Kuat \\
$0,20-0,399$ & Rendah \\
$0,00-0,199$ & Sangat Rendah \\
\hline
\end{tabular}

\subsubsection{Uji T}

Menurut Riduwan dan Akdon (2013:125) uji $t$ ini dilakukan untuk mengetahui ada tidaknya pengaruh yang signifikan antara kedua variabel maka digunakan rumus sebagai berikut:

$$
\mathrm{t}_{\text {hitung }}=\frac{r \sqrt{n-2}}{\sqrt{1-r^{2}}}
$$

Keterangan:

$\mathrm{t}_{\text {hitung }}=$ Nilai $\mathrm{t}$

$\mathrm{r} \quad=$ koefisien korelasi

$\mathrm{n} \quad=$ Banyaknya Sampel yang diamati

Dimana :

$\mathrm{t}$-hitung $\geq \mathrm{t}$-tabel yaitu t-hitung lebih kecil dari t-tabel, artinya Ho ditolak Ha diterima, sehingga antara pengembangan karir tidak ada pengaruh terhadap motivasi kerja.

t-hitung $\leq \mathrm{t}$-tabel

yaitu t-hitung lebih besar dari t-tabel, artinya Ho diterima Ha ditolak, sehingga antara pengembangan karir berpengaruh terhadap motivasi kerja.

\section{Hasil Penelitian dan Pembahasan}

\subsection{Hasil Penelitian}

\subsubsection{Deskripsi Data}

Data pada penelitian ini diperoleh dari hasil survei dengan menyebarkan kuesioner kepada 53 karyawan PT. Bank Bukopin Tbk Cabang Palembang selaku responden yang terdiri atas 24 responden laki-laki (45\%) dan 29 responden perempuan (55\%) dimana 13 responden berstatus belum menikah $(24,5 \%)$ dan 40 responden berstatus menikah $(75,5 \%)$. Adapun identitas responden berdasarkan kelompok usia dapat dilihat pada Tabel 4.1 sebagai berikut : 
Tabel 4.1 Identitas Responden Berdasarkan Kelompok Usia

\begin{tabular}{|c|c|c|}
\hline $\begin{array}{c}\text { Kelompok } \\
\text { Usia } \\
\text { (Tahun) }\end{array}$ & $\begin{array}{c}\text { Jumlah } \\
\text { Responden }\end{array}$ & $\begin{array}{c}\text { Persentase } \\
(\%)\end{array}$ \\
\hline$\leq 25$ & 2 & 3,8 \\
\hline $26-30$ & 23 & 43,4 \\
\hline $31-35$ & 18 & 34 \\
\hline$\geq 36$ & 10 & 18,8 \\
\hline Total & 53 & 100 \\
\hline
\end{tabular}

Berdasarkan Tabel 4.1 diketahui bahwa mayoritas responden penelitian berusia diantara 26 tahun sampai 30 tahun dengan persentase sebesar $43, \%$. Sementara itu, responden dengan kelompok usia kurang dari 25 tahun adalah responden dengan persentase paling kecil yaitu hanya sebesar $3,8 \%$. Adapun identitas responden berdasarkan pendidikan terakhir dapat dilihat pada Tabel 4.2 sebagai berikut :

Tabel 4.2 Identitas Responden Berdasarkan Latar Belakang Pendidikan

\begin{tabular}{|c|c|c|}
\hline $\begin{array}{c}\text { Pendidikan } \\
\text { Terakhir }\end{array}$ & $\begin{array}{c}\text { Jumlah } \\
\text { Responden }\end{array}$ & $\begin{array}{c}\text { Persentase } \\
(\%)\end{array}$ \\
\hline $\begin{array}{c}\text { SMA/ } \\
\text { Sederajat }\end{array}$ & 0 & 0 \\
\hline D1 - D3 & 9 & 17 \\
\hline S1 & 44 & 83 \\
\hline Lainnya & 0 & 0 \\
\hline Total & 53 & 100 \\
\hline
\end{tabular}

Berdasarkan Tabel 4.2 diketahui bahwa sebagian besar responden berlatar belakang pendidikan S1 dengan persentase sebesar 83\% sementara sisanya berlatar belakang D1 - D3 dengan persentase sebesar 17\%.
Adapun identitas responden berdasarkan lama bekerja dapat dilihat pada Tabel 4.3 sebagai berikut :

Tabel 4.3 Identitas Responden Berdasarkan

\begin{tabular}{|c|c|c|}
\multicolumn{1}{|c}{ Lama Bekerja } \\
\hline $\begin{array}{c}\text { Lama } \\
\text { Bekerja } \\
\text { (Tahun) }\end{array}$ & $\begin{array}{c}\text { Jumlah } \\
\text { Responden }\end{array}$ & $\begin{array}{c}\text { Persentase } \\
(\%)\end{array}$ \\
\hline $1-5$ & 39 & 73,6 \\
\hline $6-10$ & 14 & 26,4 \\
\hline$\geq 11$ & 0 & 0 \\
\hline Total & 53 & 100 \\
\hline
\end{tabular}

Berdasarkan Tabel 4.3 diketahui bahwa sebagian besar responden telah bekerja di PT. Bank Bukopin Tbk Cabang Palembang selama 1 sampai 5 tahun dengan persentase sebesar $73,6 \%$ sementara sisanya telah bekerja di PT. Bank Bukopin Tbk Cabang Palembang selama 6 sampai 10 tahun dengan persentase sebesar $26,4 \%$.

\subsubsection{Uji Validitas}

Uji validitas kuesioner pada penelitian ini dilakukan dengan alat bantu program komputer SPSS 16.0 dengan melihat hasil keluaran pada kolom Corrected Item-Total Correlation. Hasil tersebut kemudian dibandingkan dengan nilai pada tabel $r$ dengan nilai $a=5 \%$ dan nilai $d f=n-2=53-2=51 \quad$ yaitu $r_{0,05 i 51}=0,2706$. Apabila nilai korelasi suatu pertanyaan lebih besar dari nilai $r_{0,05: 51}$ maka butir pertanyaan tersebut dapat dikatakan valid dan begitu pula sebaliknya. Hasil uji validitas untuk setiap pertanyaan pada penelitian ini dapat dilihat pada Tabel 4.4

Tabel 4.4 Hasil Uji Validitas Kuesioner untuk Setiap Pertanyaan

\begin{tabular}{|c|c|c|c|}
\hline Variabel & Nomor Pertanyaan & Korelasi & Keterangan \\
\hline \multirow{4}{*}{$\boldsymbol{X}$} & 1 & 0,530 & Valid \\
\cline { 2 - 4 } & 2 & 0,302 & Valid \\
\cline { 2 - 4 } & 3 & 0,399 & Valid \\
\cline { 2 - 4 } & 4 & 0,563 & Valid \\
\cline { 2 - 4 } & 5 & 0,526 & Valid \\
\cline { 2 - 4 } & 6 & 0,570 & Valid \\
\hline
\end{tabular}




\begin{tabular}{|c|c|c|c|}
\hline \multirow{4}{*}{} & 7 & 0,332 & Valid \\
\cline { 2 - 4 } & 8 & 0,479 & Valid \\
\cline { 2 - 4 } & 9 & 0,422 & Valid \\
\hline \multirow{4}{*}{$\boldsymbol{Y}$} & 10 & 0,626 & Valid \\
\cline { 2 - 4 } & 11 & 0,591 & Valid \\
\cline { 2 - 4 } & 12 & 0,360 & Valid \\
\cline { 2 - 4 } & 13 & 0,457 & Valid \\
\cline { 2 - 4 } & 14 & 0,671 & Valid \\
\hline
\end{tabular}

Pada Tabel 4.4 terlihat bahwa nilai korelasi untuk setiap pertanyaan lebih besar dari nilai $r_{0,05: 51}=0,2706$. Untuk itu dapat disimpulkan bahwa setiap pertanyaan pada kuesioner valid.

\subsubsection{Uji Reliabilitas}

Tahap selanjutnya setelah data dikategorikan valid adalah melakukan uji reliabilitas terhadap masing-masing variabel yang diamati. Uji reliabilitas pada penelitian ini dilakukan dengan alat bantu program komputer SPSS 16.0 dengan melihat nilai pada kolom Cronbach's Alpha. Suatu variabel dikatakan reliabel apabilai memberikan nilai Cronbach's Alpha $>0,6$. Hasil Cronbach's Alpha untuk variabel $X$ dan $Y$ dapat dilihat pada Tabel 4.5

Tabel 4.5 Hasil Cronbach's Alpha untuk Variabel $X$ dan $Y$ :

\begin{tabular}{|c|c|c|}
\hline Variabel & $\begin{array}{c}\text { Hasil } \\
\text { Cronbach's } \\
\text { Alpha }\end{array}$ & Keterangan \\
\hline$X$ & 0,767 & Reliabel \\
\hline$Y$ & 0,792 & Reliabel \\
\hline
\end{tabular}

\subsubsection{Analisis Regresi Linier Sederhana}

Untuk menentukan persamaan regresi pada penelitian ini dilakukan dengan metode kuadrat terkecil. Adapun nilai unuk variabel $X$ dan $Y$ diperoleh dengan merata-ratakan nilai pada setiap pertanyaan pada masingmasing variabel $X$ dan $Y$ untuk setiap responden. Adapun nilai variabel $X$ dan $Y$ dapat dilihat pada Lampiran. Berikut dilakukan perhitungan persamaan regresi dengan diketahui sebagai berikut :

$$
\begin{array}{llll}
\Sigma X & =215,22 & \Sigma X^{2} & =877,25 \\
\Sigma Y & =208,2 & \Sigma Y^{2} & =824,6
\end{array}
$$

$$
\begin{array}{ll}
\sum X Y \quad=848,1 & n=53 \\
\sum X \sum Y=44809,27 &
\end{array}
$$

Sehingga untuk memperoleh nilai $a$ berdasarkan persamaan pada Sub Bab 3.7.1 adalah sebagai berikut :

$$
\begin{aligned}
& \text { A. } \quad=\frac{\left(\sum y\right)\left(\sum x^{2}\right)-\left(\sum x\right)\left(\sum x y\right)}{n \sum x^{2}-\left(\sum x\right)^{2}} \\
& =\frac{(208,2)(877,25)-(215,22)(848,1)}{53(877,25)-(215,22)^{2}} \\
& =\frac{115,232}{173,48} \\
& =0,664
\end{aligned}
$$

Diperoleh nilai $a$ adalah sebesar 0,664. Selanjutnya untuk memperoleh nilai $b$ persamaan pada Sub Bab 3.7.1 adalah sebagai berikut :

$$
\text { B. } \quad \begin{aligned}
& =\frac{n \sum x y-\left(\sum x\right)\left(\sum y\right)}{n \sum x^{2}-\left(\sum x\right)^{2}} \\
& =\frac{53(948,1)-(215,22)(208,2)}{53(877,25)-(215,22)^{2}} \\
& =\frac{139,44}{173,48} \\
& =0,804
\end{aligned}
$$

Diperoleh nilai $b$ adalah sebesar 0,804 . Dengan demikian, persamaan regresi linier $Y$ terhadap $X$ adalah sebagai berikut :

\section{$\widetilde{\boldsymbol{Y}}=0,664+0,804 X$}

Untuk persamaan diatas nilai $b$ bertanda positif yang berarti bahwa untuk setiap pengembangan karir $(X)$ yang bertambah sebesar 1 maka rata-rata motivasi kerja $(Y)$ bertambah sebesar 0,804 . 


\subsubsection{Analisis Koefisien Determinasi dan Koefisien Korelasi}

Perhitungan koefisien determinasi berdasarkan Persamaan pada Sub-bab 3.7.2 dengan diketahui nilai-nilai variabel seperti yang tercantum pada Sub-bab 4.2.3 adalah sebagai berikut :

$$
\begin{aligned}
r^{2} & =\frac{b\left(n\left(\sum X Y\right)-\left(\sum X\right) \cdot\left(\sum Y\right)\right)}{\sqrt{n \sum Y^{2}-(Y)^{2}}} \\
& =\frac{0,804(53(848,1)-(215,22)(208,2)}{\sqrt{(53)(824,6)-(208,2)^{2}}} \\
& =\frac{112,113}{356,56} \\
& =0,314
\end{aligned}
$$

Dari perhitungan diatas diperoleh nilai koefisien determinasi sebesar 0,341 . Hal ini menunjukkan bahwa besarnya pengaruh pengembangan karir terhadap motivasi kerja karyawan PT. Bank Bukopin Tbk Cabang Palembang adalah sebesar 34,1\%, sedangkan sisanya sebesar $100 \%-34,1 \%=$ $65,9 \%$ diperngaruhi oleh variabel lain diluar model regresi. Adapun nilai koefisien korelasi dihitung sebagai berikut :

$$
\begin{aligned}
\mathrm{r} & =\sqrt{r^{2}} \\
= & \sqrt{0,314} \\
= & 0,561
\end{aligned}
$$

Dari perhitungan diatas diperoleh nilai koefisien korelasi sebesar 0,561. Nilai tersebut menunjukkan bahwa terdapat hubungan yang kuat antara pengembangan karir dan motivasi kerja karyawan PT. Bank Bukopin Tbk Cabang Palembang.

\subsubsection{Uji T}

Uji $\mathrm{T}$ pada dasarnya menunjukkan apakah suatu variabel bebas secara individu memiliki pengaruh yang signifikan terhadap variabel bebasnya. Adapun hipotesis yang diuji adalah sebagai berikut :

$$
\begin{array}{r}
H_{0}=\text { Pengembangan karir tidak memiliki } \\
\text { pengaruh signifikan terhadap motivasi }
\end{array}
$$

kerja karyawan PT. Bank Bukopin Tbk Cabang Palembang

$H_{a}=$ Pengembangan karir memiliki pengaruh signifikan terhadap motivasi kerja karyawan PT. Bank Bukopin Tbk Cabang Palembang

$$
\text { Adapun perhitungan nilai } t_{\text {hitung }}
$$

berdasarkan Persamaan 3.7.4 adalah sebagai berikut :

$$
\begin{aligned}
t_{\text {hitung }}= & \frac{r \sqrt{n-2}}{\sqrt{1-r^{2}}} \\
= & \frac{0,561 \sqrt{53-2}}{\sqrt{1-0,314}} \\
& =\frac{4}{0,828} \\
& =4,83
\end{aligned}
$$

Dari perhitungan diatas diperoleh nilai $t_{\text {hitung }}$ sebesar 4,83 . Nilai $t_{\text {hitung }}$ tersebut kemudian dibandingkan dengan nilai $t_{\text {rabal }}$ dengan $\alpha=5 \%$ dan df $=53-1=52$ yaitu

$t_{0,05: 52}=2,00665$ yang hasilnya menyatakan bahwa nilai $t_{\text {hitung }}>t_{\text {tabel }}$. Hal ini berarti $H_{0}$ ditolak sehingga dapat disimpulkan bahwa pengembangan karir memiliki pengaruh signifikan terhadap motivasi kerja karyawan PT. Bank Bukopin Tbk Cabang Palembang.

\subsection{Pembahasan}

Setelah dilakukan analisis regresi linier sederhana, koefisien determinasi, koefisien korelasi dan uji t dari data yang diolah maka dapat diuraikan hal-hal sebagai berikut :

Berdasarkan analisis regresi linear sederhana diperoleh persamaan $\hat{Y}=0,664+$ $0,804 X$. Untuk persamaan diatas nilai $b$ bertanda positif yang berarti bahwa untuk setiap pengembangan karir $(X)$ yang bertambah sebesar 1 maka rata-rata motivasi kerja $(Y)$ bertambah sebesar 0,804.

Kemudian berdasarkan hasil perhitungan koefisien determinasi diperoleh sebesar 0,341 hal ini menunjukkan bahwa besarnya 
pengaruh pengembangan karir terhadap motivasi kerja karyawan PT. Bank Bukopin Tbk Cabang Palembang adalah sebesar 34,1 $\%$, sedangkan sisanya sebesar $100 \%-34,1 \%$ $=65,9 \%$ diperngaruhi oleh variabel lain diluar model regresi. Dan dari perhitungan nilai koefisien korelasi diperoleh sebesar 0,561 . Nilai tersebut menunjukkan bahwa terdapat hubungan yang kuat antara pengembangan karir dan motivasi kerja karyawan PT. Bank Bukopin Tbk Cabang Palembang.

Selanjutnya dari perhitungan uji t diperoleh nilai $t_{\text {hitung }}$ sebesar 4,83 . Nilai $t_{\text {hitung }}$ tersebut kemudian dibandingkan dengan nilai $\boldsymbol{t}_{\text {tabel }}$ dengan $\alpha=5 \%$ dan df $=53-1$ $=52$ yaitu $t_{0,05: 52}=2,00665$ yang hasilnya menyatakan bahwa nilai $t_{\text {hitung }}>t_{\text {tabsl }}$. Hal ini berarti $H_{0}$ ditolak sehingga dapat disimpulkan bahwa pengembangan karir memiliki pengaruh signifikan terhadap motivasi kerja karyawan PT. Bank Bukopin Tbk Cabang Palembang.

Hasil penelitian ini sesuai dengan teori yang dikemukakan oleh Sedarmayanti (2011:233) berpendapat bahwa: Keinginan yang terdapat pada seseorang individu yang merangsangnya melakukan tindakan (George R Terry). Proses dengan mana prilaku dibangkitkan, diarahkan dan dipertahankan selama berjalannya waktu (Porter \& Lawler). Kekuatan kecenderungan seseorang individu melibatkan diri dalam kegiatan yang berarahkan sasaran dalam pekerjaan. Ini bukan perasaan senang yang relatif terhadap hasil berbagai pekerjaan sebagaimana halnya kepuasan, tetapi lebih merupakan perasaan sedia/rela bekerja untuk mencapai tujuan pekerjaan (Richard $\mathrm{M}$ Steers).

Menurut Teori Hirarki yang dikembangkan oleh Abraham Maslow menyatakan bahwa setiap diri manusia itu terdiri atas lima tingkat kebutuhan Sedarmayanti (2011 : 234)

1. Kebutuhan Fisiologis

Kebutuhan ini merupakan kebutuhan tingkat dasar diantaranya kebutuhan rasa lapar, hauss, perlindungan, pakaian dan perumahan.

2. Kebutuhan keamanan

Yaitu kebutuhan keselamatan dan perlindungan terhadap kerugian fisik dan emosional.

3. Kebutuhan Sosial

Kebutuhan yang mencakup kasih sayang, dimiliki, diterima baik dan persahabatan.

4. Kebutuhan Penghargaan

Kebutuhan yang mencakup faktor rasa hormat internal seperti : harga diri, otonomi dan prestasi. Sedangkan faktor hormat eksternal seperti : status pengakuan dan perhatian.

5. Kebutuhan Aktualisasi diri

Yaitu dorongan untuk menjadi apa yang ia mampu, mencakup pertumbuhan, mencapai potensialnya, dan pemenuhan diri.

Hasil penelitian ini juga didukung oleh penelitian terdahulu di dalm Jurnal oleh Puji Sungkono Volume 10 No2 Januari 2013. Fakultas Ekonomi dan Bisnis Universitas Singaperbangsa Karawang Hasil perhitungan nilai $t_{\text {hitung }}$ yang lebih besar dari $t_{\text {tabel }}$ dan ini menyatakan bahwa ada pengaruh yang signifikan antara pengembangan karir terhadap motivasi kerja karyawan pada PT. Bank Bukopin Tbk. Cabang Palembang.

\section{KESIMPULAN DAN SARAN}

\subsection{Kesimpulan}

Dari hasil penelitian yang telah dilakukan dapat disimpulkan sebagai berikut

1. Persamaan regresi linier motivasi kerja karywawan PT. Bank Bukopin Tbk Cabang Palembang ( $Y$ ) terhadap pengembangan karir $(X)$ adalah $\hat{Y}=0,664+0,804 X$.

2. Besarnya pengaruh pengembangan karir terhadap motivasi kerja karyawan PT. Bank Bukopin Tbk Cabang Palembang adalah sebesar $34,1 \%$.

3. Berdasarkan hasil uji $\mathrm{T}$ disimpulkan bahwa pengembangan karir memiliki pengaruh signifikan terhadap motivasi 
kerja karyawan PT. Bank Bukopin Tbk

Cabang Palembang.

\subsection{Saran}

Dari hasil penelitian ada beberapa saran yang dapat diberikan antara lain sebagai berikut :

1. Pimpinan PT. Bank Bukopin Tbk. diharapkan dapat memberikan kesempatan yang sama pada setiap karyawan untuk mengembangkan karir seperti peluang untuk tumbuh kedepannya.

2. PT. Bank Bukopin Tbk. diharapkan memberikan pelatihan, fasilitas, serta reward kepada karyawan sehingga karyawan termotivasi dalam mengembangkan karir. Hal ini dapat membantu keberlangsungan perusahaan.

3. Perlu dilakukan penelitian selanjutnya untuk mengetahui faktor-faktor lain baik yang mempengaruhi pengembangan karir setiap karyawan.

\section{DAFTAR PUSTAKA}

Anwar Prabu Mangkunegara, Manajemen Sumber Daya Manusia Perusahaan, PT. Remaja Rosda Karya, Bandung, 2017.

Arikunto, S, Prosedur Penelitian: Suatu Pendekatan Praktik, Rineka Cipta, Jakarta, 2010

Ghozali, Aplikasi Analisis Multivariate dengan Program SPSS, Undip, Semarang, 2018.

Husein, Umar,Metode Penelitian Untuk Skripsi dan Tesis Bisnis, Edisi 11. PT Raja Grafindo Persada, Jakarta, 2016.

J. Dubrin, Andrew, Personnel and Human Resources Management, Kent Publishing Company, California, 1982.

Mudrajad Kuncoro, Metode Riset untuk Bisnis dan Ekonomi, Erlangga, Jakarta, 2014.

Munandar, A. Sunyoto, Psikologi Industri dan Organisasi, UI Press, Jakarta, 2006
Nana Sudjana, Penilaian Haasil Proses Belajar Mengajar, PT. Remaja Rosda Karya, Bandung, 2017

Pujji Sungkono,"Pengaruh Pengembangan Karir Terhadap Motivasi Kerja Karyawan Pada Pada PT. Excel Utama Indonesia Karawang.Jurnal Manajemen,Vol. 10 No. 2 Fakultas Ekonomi dan Bisnis Universitas Singaperbangsa, Karawang, 2013.

Riduwan dan Akdon, Rumus dan Data dalam Aplikasi Statistika, Alfabeta, Bandung, 2013.

Robbins, Stephen P.,Perilaku Organisasi. Edisi kesepuluh.PT Indeks Kelompok Gramedia, Jakarta, 2014.

Sedarmayanti. Manajemen Sumber Daya Manusia reformasi birokrasi dan manajemen pegawai negeri sipil. Bandung: Refika Aditama, 2011.

Umi Narimawati, Metodologi Penelitian Kuantitatif Teori dan Praktek, Agung Media, Jakarta, 2012.

Veithzal Rivai., dan Sagala Jauvani, Manajemen Sumber Daya Manusia Untuk Perusahaan, Edisi Kedua,Rajawali Pers, Jakarta, 2010. 